\title{
THE ANALYSIS OF LANGUAGE FEATURES ON NARRATIVE TEXT MADE BY SOCIAL TENTH GRADER AT SMAN 1 GROGOL KEDIRI
}

\author{
LUKI CAHYA NUGRAHA
}

\begin{abstract}
The aim of this study was to describe the using of language features on narrative text and the language features appropriateness on narrative text and the problem that made social tenth grader cannot use language features appropriately. The researcher used descriptive qualitative approach as research design. The researcher collected the data by analyzing the student narrative's language features, conducting interview with random students from five classes, and collecting document that supported this research. The data were collected from a Google form, interview script, and student's narrative text regarding their writing experiences. The techniques of analyzing data were reduction the data, data analysis, presenting the data, and drawing conclusion. The result of this study showed that most of the social tenth grader were using language features on their narrative text such as Action verb, Time Sequence, Simple past tense, Descriptive language, and Specific Characters. But, none of their using Dialogue, Direct and Indirect speech on making narrative text. From Google form, the result showed that most of the student answered the question about narrative's language features with the right respond. Then from interview, the result showed that the reason why the social tenth grader didn't use language features on their narrative text was due to the ignorance about the features itself.
\end{abstract}

Keywords: Google form, narrative text, writing skill, language features

\section{INTRODUCTION}

In Indonesia, English was one of compulsory subjects in Indonesian schools. It was important for students to learn English well because they accessed information from other countries. By mastering English, they're able to communicate and exchanged their views with people in the world. Therefore, Indonesian schools taught English as a second language. Richards and Renandya (2002: 303) state that there is no doubt that writing is the most difficult skill for L2 learners to master. The difficulty lies not only in generating and organizing ideas, but also in translating these ideas into readable text. Harmer (2004: 3) stated that it is worth remembering that most exams, whether they were testing foreign language abilities or other skills, often rely on the students' writing proficiency in order to measure their knowledge. Writing became one of the way to access students' English ability on making narrative text in learning.

Since writing was significant, there were twelve types of text stated in syllabus for Senior High School student, they were procedure, descriptive, recount, narrative and report, news item, analytical exposition, persuasive 
exposition, spoof, explanation, discussion, and review (depdiknas, 2006). Narrative text was to amuse or entertain the readers with actual or imaginary experiences in difference ways. Narratives always deal with some problems which lead to the climax and then turned into a solution to the problem (Sudarwati and Grace :2007 : 62). Moreover, (Derewianka, 1990) described that narrative had some components of language features, those were; chose the descriptive language to enhance and developed the story by creating images in the readers' mind, and the last participant might be written in the first person (I, we) or third person (he, she, they). It also mentioned in detail that narrative's language features were consist of the used of specific participants; mainly used action verbs; used temporal conjunction and temporal circumstances; used past tense as dominant tense; and used relational and mental process.

\section{RESEARCH METHOD}

This research was a descriptive qualitative. The researcher used a qualitative descriptive design which the researcher used words to describe the particular thing that will be explained. The researcher chose the place of research in SMAN 1 Grogol. The location of this school at Raya Gringging street No.16, Grogol, kediri, East Java 64151 (0354) 773009 and the website http://sman1grogol.sch.id. In this research, the researcher used five class there are X-IIS 1, X-IIS 2, X-IIS 3, X-IIS 4, and X-IIS 5. The students who studied in SMAN 1 Grogol Kediri were varied from fresh high school graduates either they took English course before or not, English courses' tutors and school teachers. Based on these reasons, the researcher took these class as subjects of his research. So, it was expected that the result of the study might helped students to know their weaknesses and to create a good writing on narrative text in the future.

The social tenth graders, which was taken as the subject of research, had five classes. Among this class number (thirty five STD in each class), the researcher used Slovin Formula (Riduwan, 2005:65) such as :

$\mathrm{n}=\frac{N}{N(d) 2}+1$

With the description like this :

$\mathrm{n}=$ Sample; $\mathrm{N}=$ Population; $\mathrm{d}=$ pretition mark $95 \%$ or sig. $=0,05$

The population of social tenth graders at SMAN 1 Grogol Kediri was 175, and the error rate as desire was $0,05 \%$. So the researcher used the formula to get the sample that needed such as below :

$\mathrm{n}=\frac{175}{175(0,05) 2}+1$

$\mathrm{n}=24,5$ (then the researcher made it be, $\mathrm{n}=25$ )

According to the counting above, the researcher took twenty five STD for each class. Then, the researcher took two STD who were stand out and took two STD who weren't stand out based on the teacher's documentation. The STD were took to make the research related to analyze the language features on narrative 
text done smoothly. Then, the researcher used Google form, student's worksheet and interview for the instrument.

\section{FINDING AND DISCUSSION}

The first focus of this research identified the language features on narrative text made by social tenth graders at SMAN 1 Grogol Kediri. Based on 125 narrative texts written by 125 students, the researcher wanted to analyze the language features that used by themselves. The data about respondent and what language features that mentioned was arranged into table. (see Table 4.1)

Table 4.1 Respondent Data

\begin{tabular}{|c|l|c|c|c|c|c|c|c|}
\hline \multirow{2}{*}{ No } & \multirow{2}{*}{ Student's Name } & \multicolumn{7}{|c|}{ Narrative's Language Features } \\
\cline { 3 - 8 } & & 1 & 2 & 3 & 4 & 5 & 6 & 7 \\
\hline 1 & A. Choirul Umam & $\sqrt{ }$ & - & - & - & $\sqrt{ }$ & $\sqrt{ }$ & $\sqrt{ }$ \\
\hline 2 & Alfiyah Nuraini & $\sqrt{ }$ & - & - & - & $\sqrt{ }$ & $\sqrt{ }$ & $\sqrt{ }$ \\
\hline 3 & Dwi Rangga Y. & $\sqrt{ }$ & - & - & - & $\sqrt{ }$ & $\sqrt{ }$ & $\sqrt{ }$ \\
\hline 4 & Qoirul Rohqim & $\sqrt{ }$ & - & - & $\sqrt{ }$ & $\sqrt{ }$ & $\sqrt{ }$ & $\sqrt{ }$ \\
\hline 5 & Yeriko Kartika H. & $\sqrt{ }$ & - & - & $\sqrt{ }$ & $\sqrt{ }$ & $\sqrt{ }$ & $\sqrt{ }$ \\
\hline 6 & Ana Nur K. & $\sqrt{ }$ & - & - & $\sqrt{ }$ & $\sqrt{ }$ & $\sqrt{ }$ & $\sqrt{ }$ \\
\hline 7 & Dian Sri Utami & $\sqrt{ }$ & - & - & - & $\sqrt{ }$ & $\sqrt{ }$ & $\sqrt{ }$ \\
\hline 8 & Febyyan Golfinda P. & $\sqrt{ }$ & - & - & - & $\sqrt{ }$ & $\sqrt{ }$ & $\sqrt{ }$ \\
\hline 9 & Laili Nur Maulina S. & $\sqrt{ }$ & - & - & - & $\sqrt{ }$ & $\sqrt{ }$ & $\sqrt{ }$ \\
\hline 10 & Moch. Rega Ilham & $\sqrt{ }$ & - & - & - & $\sqrt{ }$ & $\sqrt{ }$ & $\sqrt{ }$ \\
\hline 11 & Astin Nurhidayah S. & $\sqrt{ }$ & - & - & $\sqrt{ }$ & $\sqrt{ }$ & $\sqrt{ }$ & $\sqrt{ }$ \\
\hline 12 & Bima Surya P. & $\sqrt{ }$ & - & - & - & $\sqrt{ }$ & $\sqrt{ }$ & $\sqrt{ }$ \\
\hline 13 & Nova Dwinda A. & $\sqrt{ }$ & - & - & - & $\sqrt{ }$ & $\sqrt{ }$ & $\sqrt{ }$ \\
\hline 14 & Rivan Hari S. & $\sqrt{ }$ & - & - & - & $\sqrt{ }$ & $\sqrt{ }$ & $\sqrt{ }$ \\
\hline 15 & Tiara Pratama Wati & $\sqrt{ }$ & - & - & - & $\sqrt{ }$ & $\sqrt{ }$ & $\sqrt{ }$ \\
\hline 16 & Reza C. Z. & $\sqrt{ }$ & - & - & - & $\sqrt{ }$ & $\sqrt{ }$ & $\sqrt{ }$ \\
\hline 17 & Della Fitri Alrinjani & $\sqrt{ }$ & - & - & - & $\sqrt{ }$ & $\sqrt{ }$ & $\sqrt{ }$ \\
\hline 18 & Kusuma Nandita & $\sqrt{ }$ & - & - & - & $\sqrt{ }$ & $\sqrt{ }$ & $\sqrt{ }$ \\
\hline 19 & Niken Tria F. & $\sqrt{ }$ & - & - & - & $\sqrt{ }$ & $\sqrt{ }$ & $\sqrt{ }$ \\
\hline 20 & Yusinta Agustina & $\sqrt{ }$ & - & - & - & $\sqrt{ }$ & $\sqrt{ }$ & $\sqrt{ }$ \\
\hline 21 & Lili Kartika Sari & $\sqrt{ }$ & - & - & - & $\sqrt{ }$ & $\sqrt{ }$ & $\sqrt{ }$ \\
\hline 22 & Dwiki Mahendra & $\sqrt{ }$ & - & - & - & $\sqrt{ }$ & $\sqrt{ }$ & $\sqrt{ }$ \\
\hline 23 & Nirvani Ardi & $\sqrt{ }$ & - & - & - & $\sqrt{ }$ & $\sqrt{ }$ & $\sqrt{ }$ \\
\hline 24 & Yogi Setiawan P. & $\sqrt{ }$ & - & - & - & $\sqrt{ }$ & $\sqrt{ }$ & $\sqrt{ }$ \\
\hline 25 & Naning Indah K. & $\sqrt{ }$ & - & - & - & $\sqrt{ }$ & $\sqrt{ }$ & $\sqrt{ }$ \\
\hline 26 & Deny Agung & $\sqrt{ }$ & - & - & - & $\sqrt{ }$ & $\sqrt{ }$ & $\sqrt{ }$ \\
\hline
\end{tabular}




\begin{tabular}{|c|c|c|c|c|c|c|c|c|}
\hline 27 & Priya Herlambang P. & $\sqrt{ }$ & - & - & - & $\sqrt{ }$ & $\sqrt{ }$ & $\sqrt{ }$ \\
\hline 28 & Putri Ningtyas R. & $\sqrt{ }$ & - & - & - & $\sqrt{ }$ & $\sqrt{ }$ & $\sqrt{ }$ \\
\hline 29 & Puji Yuliati & $\sqrt{ }$ & - & - & - & $\sqrt{ }$ & $\sqrt{ }$ & $\sqrt{ }$ \\
\hline 30 & Tata Fauziah S. & $\sqrt{ }$ & - & - & - & $\sqrt{ }$ & $\sqrt{ }$ & $\sqrt{ }$ \\
\hline 31 & Novi Laviana & $\sqrt{ }$ & - & - & - & $\sqrt{ }$ & $\sqrt{ }$ & $\sqrt{ }$ \\
\hline 32 & Yahri Nanda W. & $\sqrt{ }$ & - & - & - & $\sqrt{ }$ & $\sqrt{ }$ & $\sqrt{ }$ \\
\hline 33 & Irma Rosalina & $\sqrt{ }$ & - & - & - & $\sqrt{ }$ & $\sqrt{ }$ & $\sqrt{ }$ \\
\hline 34 & Anis Kumala Sari & $\sqrt{ }$ & - & - & - & $\sqrt{ }$ & $\sqrt{ }$ & $\sqrt{ }$ \\
\hline 35 & Wildan Chika Pradana & $\sqrt{ }$ & - & - & - & $\sqrt{ }$ & $\sqrt{ }$ & $\sqrt{ }$ \\
\hline 36 & Zanuar Ari S. & $\sqrt{ }$ & - & - & - & $\sqrt{ }$ & $\sqrt{ }$ & $\sqrt{ }$ \\
\hline 37 & Setiawan Budi Raharja & $\sqrt{ }$ & - & - & - & $\sqrt{ }$ & $\sqrt{ }$ & $\sqrt{ }$ \\
\hline 38 & Dita Kusuma & $\sqrt{ }$ & - & - & - & $\sqrt{ }$ & $\sqrt{ }$ & $\sqrt{ }$ \\
\hline 39 & Ribet Effendi & $\sqrt{ }$ & - & - & - & $\sqrt{ }$ & $\sqrt{ }$ & $\sqrt{ }$ \\
\hline 40 & Da'u Kusuma & $\sqrt{ }$ & - & - & - & $\sqrt{ }$ & $\sqrt{ }$ & $\sqrt{ }$ \\
\hline 41 & Titin Asri Wulandari & $\sqrt{ }$ & - & - & - & $\sqrt{ }$ & $\sqrt{ }$ & $\sqrt{ }$ \\
\hline 42 & Tobi R. & $\sqrt{ }$ & - & - & - & $\sqrt{ }$ & $\sqrt{ }$ & $\sqrt{ }$ \\
\hline 43 & Dwi Jatu & $\sqrt{ }$ & - & - & - & $\sqrt{ }$ & $\sqrt{ }$ & $\sqrt{ }$ \\
\hline 44 & Izza Puri M. & $\sqrt{ }$ & - & - & - & $\sqrt{ }$ & $\sqrt{ }$ & $\sqrt{ }$ \\
\hline 45 & Danu Prayogo & $\sqrt{ }$ & - & - & - & $\sqrt{ }$ & $\sqrt{ }$ & $\sqrt{ }$ \\
\hline 46 & Aset Arga P. & $\sqrt{ }$ & - & - & - & $\sqrt{ }$ & $\sqrt{ }$ & $\sqrt{ }$ \\
\hline 47 & Edo Ramadhani & $\sqrt{ }$ & - & - & - & $\sqrt{ }$ & $\sqrt{ }$ & $\sqrt{ }$ \\
\hline 48 & Nisca Elisia K. & $\sqrt{ }$ & - & - & - & $\sqrt{ }$ & $\sqrt{ }$ & $\sqrt{ }$ \\
\hline 49 & M. Kurniawan & $\sqrt{ }$ & - & - & - & $\sqrt{ }$ & $\sqrt{ }$ & $\sqrt{ }$ \\
\hline 50 & Moh. Adi Wijaya & $\sqrt{ }$ & - & - & - & $\sqrt{ }$ & $\sqrt{ }$ & $\sqrt{ }$ \\
\hline 51 & Syafa Chamella & $\sqrt{ }$ & - & - & - & $\sqrt{ }$ & $\sqrt{ }$ & $\sqrt{ }$ \\
\hline 52 & Irsyad Sudiro & $\sqrt{ }$ & - & - & - & $\sqrt{ }$ & $\sqrt{ }$ & $\sqrt{ }$ \\
\hline 53 & Evi Wulan S. & $\sqrt{ }$ & - & - & - & $\sqrt{ }$ & $\sqrt{ }$ & $\sqrt{ }$ \\
\hline 54 & Binawan Satrio R. & $\sqrt{ }$ & - & - & - & $\sqrt{ }$ & $\sqrt{ }$ & $\sqrt{ }$ \\
\hline 55 & Dhiki Dwi A. & $\sqrt{ }$ & - & - & - & $\sqrt{ }$ & $\sqrt{ }$ & $\sqrt{ }$ \\
\hline 56 & Dimas Budi S. & $\sqrt{ }$ & - & - & - & $\sqrt{ }$ & $\sqrt{ }$ & $\sqrt{ }$ \\
\hline 57 & Nadilla Ambarwati & $\sqrt{ }$ & - & - & - & $\sqrt{ }$ & $\sqrt{ }$ & $\sqrt{ }$ \\
\hline 58 & Maudina Pasha Shavitri & $\sqrt{ }$ & - & - & - & $\sqrt{ }$ & $\sqrt{ }$ & $\sqrt{ }$ \\
\hline 59 & Agustina Mawar C. & $\sqrt{ }$ & - & - & - & $\sqrt{ }$ & $\sqrt{ }$ & $\sqrt{ }$ \\
\hline 60 & Adel Cantika Sari & $\sqrt{ }$ & - & - & - & $\sqrt{ }$ & $\sqrt{ }$ & $\sqrt{ }$ \\
\hline 61 & Nay Fahma T. & $\sqrt{ }$ & - & - & - & $\sqrt{ }$ & $\sqrt{ }$ & $\sqrt{ }$ \\
\hline 62 & Riris Agustina W. & $\sqrt{ }$ & - & - & - & $\sqrt{ }$ & $\sqrt{ }$ & $\sqrt{ }$ \\
\hline 63 & Aditya Fallen L. & $\sqrt{ }$ & - & - & - & $\sqrt{ }$ & $\sqrt{ }$ & $\sqrt{ }$ \\
\hline
\end{tabular}




\begin{tabular}{|c|c|c|c|c|c|c|c|c|}
\hline 64 & Murni Aisyah A. & $\sqrt{ }$ & - & - & - & $\sqrt{ }$ & $\sqrt{ }$ & $\sqrt{ }$ \\
\hline 65 & Taufiq Muqarrabin & $\sqrt{ }$ & - & - & - & $\sqrt{ }$ & $\sqrt{ }$ & $\sqrt{ }$ \\
\hline 66 & Saskia Putri M. & $\sqrt{ }$ & - & - & - & $\sqrt{ }$ & $\sqrt{ }$ & $\sqrt{ }$ \\
\hline 67 & Adinda Kumala S. & $\sqrt{ }$ & - & - & - & $\sqrt{ }$ & $\sqrt{ }$ & $\sqrt{ }$ \\
\hline 68 & Putri Wahyu Ningsih & $\sqrt{ }$ & - & - & - & $\sqrt{ }$ & $\sqrt{ }$ & $\sqrt{ }$ \\
\hline 69 & Imam Suwardi & $\sqrt{ }$ & - & - & - & $\sqrt{ }$ & $\sqrt{ }$ & $\sqrt{ }$ \\
\hline 70 & Nasa D. Fariz & $\sqrt{ }$ & - & - & - & $\sqrt{ }$ & $\sqrt{ }$ & $\sqrt{ }$ \\
\hline 71 & Putri Wahyuni S. & $\sqrt{ }$ & - & - & - & $\sqrt{ }$ & $\sqrt{ }$ & $\sqrt{ }$ \\
\hline 72 & Sofia Azzarah & $\sqrt{ }$ & - & - & - & $\sqrt{ }$ & $\sqrt{ }$ & $\sqrt{ }$ \\
\hline 73 & Ganes Salma A. & $\sqrt{ }$ & - & - & - & $\sqrt{ }$ & $\sqrt{ }$ & $\sqrt{ }$ \\
\hline 74 & Evan Lutfi P. & $\sqrt{ }$ & - & - & - & $\sqrt{ }$ & $\sqrt{ }$ & $\sqrt{ }$ \\
\hline 75 & Dinni Wachidatun A. & $\sqrt{ }$ & - & - & - & $\sqrt{ }$ & $\sqrt{ }$ & $\sqrt{ }$ \\
\hline 76 & Zainal Firdaus & $\sqrt{ }$ & - & - & - & $\sqrt{ }$ & $\sqrt{ }$ & $\sqrt{ }$ \\
\hline 77 & M. Sholiqin & $\sqrt{ }$ & - & - & - & $\sqrt{ }$ & $\sqrt{ }$ & $\sqrt{ }$ \\
\hline 78 & Moh. Guntur & $\sqrt{ }$ & - & - & - & $\sqrt{ }$ & $\sqrt{ }$ & $\sqrt{ }$ \\
\hline 79 & Chitra Atika M. & $\sqrt{ }$ & - & - & - & $\sqrt{ }$ & $\sqrt{ }$ & $\sqrt{ }$ \\
\hline 80 & Binta Darmiyanti & $\sqrt{ }$ & - & - & - & $\sqrt{ }$ & $\sqrt{ }$ & $\sqrt{ }$ \\
\hline 81 & Achmad Nanang & $\sqrt{ }$ & - & - & - & $\sqrt{ }$ & $\sqrt{ }$ & $\sqrt{ }$ \\
\hline 82 & Vero Muhajji & $\sqrt{ }$ & - & - & - & $\sqrt{ }$ & $\sqrt{ }$ & $\sqrt{ }$ \\
\hline 83 & Danang Prambudi L. & $\sqrt{ }$ & - & - & - & $\sqrt{ }$ & $\sqrt{ }$ & $\sqrt{ }$ \\
\hline 84 & Nur. Laili Wachidatun & $\sqrt{ }$ & - & - & - & $\sqrt{ }$ & $\sqrt{ }$ & $\sqrt{ }$ \\
\hline 85 & Sindi Mayang B. & $\sqrt{ }$ & - & - & - & $\sqrt{ }$ & $\sqrt{ }$ & $\sqrt{ }$ \\
\hline 86 & Afwan Sugiarto & $\sqrt{ }$ & - & - & - & $\sqrt{ }$ & $\sqrt{ }$ & $\sqrt{ }$ \\
\hline 87 & Dian Darma P. & $\sqrt{ }$ & - & - & - & $\sqrt{ }$ & $\sqrt{ }$ & $\sqrt{ }$ \\
\hline 88 & Ramadhan Dwi E. & $\sqrt{ }$ & - & - & - & $\sqrt{ }$ & $\sqrt{ }$ & $\sqrt{ }$ \\
\hline 89 & Novia Agusvina & $\sqrt{ }$ & - & - & - & $\sqrt{ }$ & $\sqrt{ }$ & $\sqrt{ }$ \\
\hline 90 & Nada Husna Abidah & $\sqrt{ }$ & - & - & - & $\sqrt{ }$ & $\sqrt{ }$ & $\sqrt{ }$ \\
\hline 91 & Muhammad Nizar A. & $\sqrt{ }$ & - & - & - & $\sqrt{ }$ & $\sqrt{ }$ & $\sqrt{ }$ \\
\hline 92 & Anita Nurul Indah Sari & $\sqrt{ }$ & - & - & - & $\sqrt{ }$ & $\sqrt{ }$ & $\sqrt{ }$ \\
\hline 93 & Emma Nur Azizah & $\sqrt{ }$ & - & - & - & $\sqrt{ }$ & $\sqrt{ }$ & $\sqrt{ }$ \\
\hline 94 & Aishaa Safannah Z. & $\sqrt{ }$ & - & - & - & $\sqrt{ }$ & $\sqrt{ }$ & $\sqrt{ }$ \\
\hline 95 & Bima Apriandi & $\sqrt{ }$ & - & - & - & $\sqrt{ }$ & $\sqrt{ }$ & $\sqrt{ }$ \\
\hline 96 & Dani Yunanta P. & $\sqrt{ }$ & - & - & - & $\sqrt{ }$ & $\sqrt{ }$ & $\sqrt{ }$ \\
\hline 97 & Rachmad Kuncara & $\sqrt{ }$ & - & - & - & $\sqrt{ }$ & $\sqrt{ }$ & $\sqrt{ }$ \\
\hline 98 & Willy Noside A. & $\sqrt{ }$ & - & - & - & $\sqrt{ }$ & $\sqrt{ }$ & $\sqrt{ }$ \\
\hline 99 & Achamad Resa & $\sqrt{ }$ & - & - & - & $\sqrt{ }$ & $\sqrt{ }$ & $\sqrt{ }$ \\
\hline 100 & Siska Kusuma W. & $\sqrt{ }$ & - & - & - & $\sqrt{ }$ & $\sqrt{ }$ & $\sqrt{ }$ \\
\hline
\end{tabular}




\begin{tabular}{|l|l|c|c|c|c|c|c|c|}
\hline 101 & Ari Yudha Herlambang & $\sqrt{ }$ & - & - & - & $\sqrt{ }$ & $\sqrt{ }$ & $\sqrt{ }$ \\
\hline 102 & Umar Nayiry Shaleh & $\sqrt{ }$ & - & - & - & $\sqrt{ }$ & $\sqrt{ }$ & $\sqrt{ }$ \\
\hline 103 & Natasha W. & $\sqrt{ }$ & - & - & - & $\sqrt{ }$ & $\sqrt{ }$ & $\sqrt{ }$ \\
\hline 104 & Ilham Putra S. & $\sqrt{ }$ & - & - & - & $\sqrt{ }$ & $\sqrt{ }$ & $\sqrt{ }$ \\
\hline 105 & Calista Adeline & $\sqrt{ }$ & - & - & - & $\sqrt{ }$ & $\sqrt{ }$ & $\sqrt{ }$ \\
\hline 106 & Adelya Fer Hidayat & $\sqrt{ }$ & - & - & - & $\sqrt{ }$ & $\sqrt{ }$ & $\sqrt{ }$ \\
\hline 107 & Zubaier H. & $\sqrt{ }$ & - & - & - & $\sqrt{ }$ & $\sqrt{ }$ & $\sqrt{ }$ \\
\hline 108 & Hhimawan Dwi & $\sqrt{ }$ & - & - & - & $\sqrt{ }$ & $\sqrt{ }$ & $\sqrt{ }$ \\
\hline 109 & M. Akbar Kafi & $\sqrt{ }$ & - & - & - & $\sqrt{ }$ & $\sqrt{ }$ & $\sqrt{ }$ \\
\hline 110 & Satria Galang K. & $\sqrt{ }$ & - & - & - & $\sqrt{ }$ & $\sqrt{ }$ & $\sqrt{ }$ \\
\hline 111 & Bagus Ari Sudewo & $\sqrt{ }$ & - & - & - & $\sqrt{ }$ & $\sqrt{ }$ & $\sqrt{ }$ \\
\hline 112 & Onnyk Narriranti & $\sqrt{ }$ & - & - & - & $\sqrt{ }$ & $\sqrt{ }$ & $\sqrt{ }$ \\
\hline 113 & Dwija Panji Suryana & $\sqrt{ }$ & - & - & - & $\sqrt{ }$ & $\sqrt{ }$ & $\sqrt{ }$ \\
\hline 114 & Ridwan Arif Dwi & $\sqrt{ }$ & - & - & - & $\sqrt{ }$ & $\sqrt{ }$ & $\sqrt{ }$ \\
\hline 115 & Claudya Silvi & $\sqrt{ }$ & - & - & - & $\sqrt{ }$ & $\sqrt{ }$ & $\sqrt{ }$ \\
\hline 116 & Sandy Ramadhan & $\sqrt{ }$ & - & - & - & $\sqrt{ }$ & $\sqrt{ }$ & $\sqrt{ }$ \\
\hline 117 & Danu Wijaya & $\sqrt{ }$ & - & - & - & $\sqrt{ }$ & $\sqrt{ }$ & $\sqrt{ }$ \\
\hline 118 & Hary Kristiyanto & $\sqrt{ }$ & - & - & - & $\sqrt{ }$ & $\sqrt{ }$ & $\sqrt{ }$ \\
\hline 119 & Ruli Kristianti A. & $\sqrt{ }$ & - & - & - & $\sqrt{ }$ & $\sqrt{ }$ & $\sqrt{ }$ \\
\hline 120 & Nosy Fietdian Dwiki & $\sqrt{ }$ & - & - & - & $\sqrt{ }$ & $\sqrt{ }$ & $\sqrt{ }$ \\
\hline 121 & Nur Khamim & $\sqrt{ }$ & - & - & - & $\sqrt{ }$ & $\sqrt{ }$ & $\sqrt{ }$ \\
\hline 122 & Moch. Ali S. & $\sqrt{ }$ & - & - & - & $\sqrt{ }$ & $\sqrt{ }$ & $\sqrt{ }$ \\
\hline 123 & Burhan Irawan K. & $\sqrt{ }$ & - & - & - & $\sqrt{ }$ & $\sqrt{ }$ & $\sqrt{ }$ \\
\hline 124 & Irfan Bayu Mukti & $\sqrt{ }$ & - & - & - & $\sqrt{ }$ & $\sqrt{ }$ & $\sqrt{ }$ \\
\hline 125 & Ersava Rafael & $\sqrt{ }$ & - & - & - & $\sqrt{ }$ & $\sqrt{ }$ & $\sqrt{ }$ \\
\hline
\end{tabular}

Note : ( Table 4.1 For number in the kinds of narrative's language features table above)

a) 1 means Action Verb

b) 2 means Dialogue

c) 3 means Direct and Indirect Speech

d) 4 means Descriptive Language

e) 5 means Specific Characters

f) 6 means Simple Past Tense

g) 7 means Time Sequences

Note : (Table 4.1 Color Description)

\begin{tabular}{|c|}
\hline$X-$ IIS -1 \\
\hline$X-$ IIS -2 \\
\hline$X-$ IIS -3 \\
\hline$X-$ IIS -4 \\
\hline$X-$ IIS -5 \\
\hline
\end{tabular}




\section{The Analysis of Narrative's Language Features}

\section{a. Action Verb}

Verbs that express some action, most of the action verbs are defined transitive or intransitive. This means that some are used with direct object (person or thing that receives the action of the subject) and others do not need a direct object. Some verbs can be both transitive and intransitive depending on their meaning.

So, the researcher analyses do the students applied action verbs feature in their narrative text. Here's the explanations : In narrative text from STD1, the researcher found that he used A in his story, such as in "... the animal chased the gingerbread together". Continued to narrative text from STD6 who also used A in her story, such as in "... the gingerbread man ran out the window", "... so he could cross the river". Similar with narrative text from STD11, such as in sentences "... the woman decided to make a gingerbread man for them", "he was cheated by the fox" and etc. And then, the researcher analyzes narrative text from STD16, and apparently he also used A in his story, such as in "Then, the gingerbread man asked for help to the fox", "... the fox opened his mouth and gobbled up the gingerbread man".

Narrative text, it could not be seperated from the action or activity done by the characters that mentioned, as for the events that happened in the story, and therefore the author should used action verbs in their stories. The result of narrative text students showed that overall the students already applied or used action verb feature in their narrative stories they made.

\section{b. Dialogue}

The researcher did found none of STD who were used this feature in their narrative text. From the STD1 to STD20 none who applied dialogue feature. It was not good considering that for making interesting story to the reader, the writer must put some dialogue among the characters of the story in their narrative text. In the writing narrative text, it would be nice to include dialogue, to show the interaction or communication among characters in the story, so the story feels more alive and interesting to read. But none of the STD who were used this feature, the result they only describe the story itself.

\section{c. Direct and Indirect Speech}

In narrative text, there should be direct and indirect speech, as communication between the author who tells the story to the reader, but it is also as communication among the characters in the story. Direct and indirect exists because of the dialogue, if it didn't use dialogue so only indirect that being used in the story. From STD1 to STD20, there were no one who used this feature in their story writing at all. It was not good in writing narrative text because in order to make the story ant the reading interesting, the writer must put the dialogue and automatically used direct and indirect speech on it. 


\section{d. Descriptive Language}

The researcher found this feature applied by only three STD in their story. They used this feature to describe something in the story they made. For STD5 and STD6 who made same sentence using this feature such as "So it can be looks good". In STD4, the researcher found that she used this feature in her sentence like "She then cut a lovely gingerbread manand gave him blueberries for his eyes". Then in STD11's narrative story, the researcher also found descriptive language to describe things such as "She then cut a handsome gingerbread man and gave him blueberries for his eyes". These two STD (4 and 5) almost had a similarity on their sentence when using this feature.

Descriptive language in narrative text used to describe something in the story, such as describe people or character, describ place, describe the shape of objects, or even describe events that happened in the story and etc. In this case, the researcher only found descriptive language feature in three STD among of all STD's narrative text.

\section{e. Specific Characters}

There are many specific traits every piece of narrative writing should have. Usually there are also specific types of characters needed in order to create a developed story. For example, each story will often have a protagonist, which is the hero or heroine. This is the central character of the story. Often, there is also an antagonist, which is a character who opposes the protagonist. Overall, each story needs characters to push forward or react to the events in the plot.

From the data gained by the researcher, all STD from STD1 to STD20 used this feature in their story from the STD2's narrative text such as "the fox" , " the gingerbread man", "an old woman". Then the next STD who used this feature came to STD9 like "a grandfather", "a grandmother", " $a$ gingerbread", "the fox". While the researcher found this feature on STD16 such as "an old woman", "an old man", "a gingerbread", "a pig”, "a cow", "a horse", "a fox"

This feature in narrative text made the characters that mentioned in the story be specific, not being the general one. All stories must have characters, also known as the people or subjects of the story. So, the story can be interested to read by the reader.

\section{f. Simple Past Tense}

Simple past tense must applied in narrative text, because narrative text tells about the event which already happened.

In narrative text from STD3, the researcher found that he in writing narrative text mostly used ST like in "... the woman decided to make a gingerbread man for them to eat", "... he rolled out the dough carefully". The researcher also found in the result of narrative text from STD12 using ST such as "... the gingerbread man who brave and baked by old woman moved", "... the pig who wanted to catch him". Next on STD14's narrative text which his sentences are "in a while the old woman opened the oven", "the old woman 
and man were shocked”, "... gingerbread confused where to go”, "a fox who wanted to help". Based on the result of narrative text from STD18 shows that she applied ST, for example in "she mixed flour, butter, and eggs in a bowl", "the ginigerbread man jumped out and run away", "the gingerbread man was chased by the old woman", "the gingerbread man reached the river bank".

Narrative text is kind of text that has a story of the past or story that already happened, so in writing narrative text the writer must applied ST. From all the result of STD's narrative text, the whole STD mostly used ST in their story.

\section{g. Time Sequences}

Based on the result of narrative text from STD4 showed that he used TS in the bginning of the story like "a long, long time ago". Same as STD4 case, STD5 showed that he used "a long time ago" in his narrative text as TS. Then the researcher found that STD8 used "in ancient time" at the beginning story he made to show that it was TS he used. In STD12, the researcher found that the writer used "one day" to indicate that it was TS he used. Next, STD13 put TS in her story at the first middle sentence so it looks more variative, "there lived grandparent long ago in a small cottage near the river". STD20's narrative text showed that she used "in a long ancient time" as TS feature in her story she made.

From the data gained above, it can be indicated that most of STD used TS in their writing of narrative text. TS function was to inform or tell the reader when and where the story happened. In a narrative text, generally, the writer introduce the story with a sentence like "One day", "A long time ago", "Once upon a time", and etc. at the beginning of the story.

\section{Google Form}

The second focus of this research identifies the appropriateness of language features that used on narrative text. Based on the findings, the researcher want to know that most of STD have understand and used the narrative's language features properly on the text they made. Then the researcher made a Google form, so the STD can easily be tested by answering the question related to narrative's language features given by the researcher. The form was contained 4 questions to be answered. There were :

a. Do you know about narrative text?

b. Which one is correct for the narrative text generic structure ?

c. Mention narrative's language features that you understand! (At least 3)

d. Match these kind of language features to the right example!

Link 4.1. The form that had been answered by 5 random STD https://docs.Google.com/forms/d/1re_DzzwwEeDzrgQFkAaOkvSEV01Jmzmgsd8 qnnwtmew/edit 


\section{Interview}

Besides Google form, the researcher used interview that allow the STD to refelect and reason on a variety of subjects. The researcher did interview to answer the third research focus, the researcher conducted to 4 respondents. Below were questions in interviewing :

a. Do you know about narrative text?

b. Do you know about language features on narrative text ? Mention them !

c. Do you often use language features or not on your narrative text?

d. Give me the reason why you use language features or not!

After the reasearcher took interviewing, the researcher got the answers. Below were the answer recaps :

- Interviewer : Do you know about narrative text?

Respondent 1 : Yes, I do. A text full of story like Malin Kundang, Cinderella

Respondent 2 : Yes, a little. I know it's a text with orientation, complication, and resolution

Respondent 3 : Yes, sir. It's a text with story and simple past tense

Respondent 4 : Yes, text with structural paragraph

Respondent 5 : Of course, i know. It's a text with many story that have characters, pace, and time.

- Interviewer : Have you learned narrative text before?

Respondent 1 : Yes, I have learned at Junior High School

Respondent 2 : Yes

Respondent 3 : Yes, when I'm at Junior High School. I ever describe in the class

Respondent 4 : Yeah, Junior High School, mr.

Respondent 5 : Of course, I have.

- Interviewer : Do you know about language features on narrative text? Can you mention them!

Respondent 1 : Verb, characters, and once upon a time

Respondent 2 : I don't know it. I already know that narrative text has language features, sir

Respondent 3 : I think it's simple past tense

Respondent 4 : Sure. Orientation, complication, resolution, amd, moral value

Respondent 5 : Using verb 2, characters, place, and time

- Interviewer : Do you often use language features or not on your narrative text?

Respondent 1 : Yes

Respondent 2 : I think no

Respondent 3 : Yes

Respondent 4 : Yes, maybe

Respondent 5 : Of course, yes 
- Interviewer : Give me the reason why you use language features or not!

Respondent 1 : Because Narrative text need it

Respondent 2 : Sorry sir, I don't know the answer

Respondent 3 : Because Narrative text using Verb 2, sir

Respondent 4 : I use it because it was the structures

Respondent 5 : It's Narrative text characteristic

\section{CONCLUSION}

From the findings and discussion, some conclusions can be drawn. The first was the language features that used on narrative text made by social tenth graders at SMAN 1 Grogol Kediri. The language features of the narrative text was mostly used by the STD. Eventhough most of them couldn't put the dialogue, descriptive language, direct and indirect speech in average of their narrative text.

Secondly, the social tenth graders at SMAN 1 Grogol Kediri was answering the questions on Google form that made by the researcher. From all the questions given, some of them put the right answer because they understood how to use narrative's language features properly than some of them who didn't use the narrative's language features properly.

The third was about the problems that makes the STD cannot use language features appropriately in their narrative text were dialogue, direct and indirect speech, descriptive language, simple past tense, action verb, and problems in developing ideas. Besides, based on their conversation between the STD related and the researcher through an interview, they got difficulty mostly in developing their ignorance about narrative's language features, grammar, structure problems and word choices.

\section{REFERENCES}

Depdiknas. (2006). Kurikulum Tingkat Satuan Pendidikan SMA dan MA. Jakarta: Depdiknas.

Derewianka, B. (1990). Exploring How Text Work. Australia: Primary English Teaching Association.

Harmer, Jeremy. 2004. How to Teach Writing. Harlow: Pearson Education Ltd.

Richard C.J. and Renandya A. W. 2002. Methodology in Language Teaching; An Onthology of Current Practice: Cambridge: Cambridge University Press.

Riduwan. 2005. Belajar Mudah Penelitian Untuk Guru, Karyawan dan Peneliti Pemula, Bandung : Alfabeta.

Th. Sudarwati, M. and Eudia Grace. 2007. Look Ahead Book 1: An English Course for Senior High School Students Year X. Jakarta: Erlangga 